\title{
Etika kot sredstvo proti razgradnji socialnega dela
}

Številka Socialnega dela je posvečena tematikam, ki so bile kot pomembne teme oziroma plenarna predavanja obravnavane na sedmem nacionalnem kongresu socialnega dela (z mednarodno udeležbo) oktobra 2019 v Moravskih Toplicah. Na kongresu, ki je imel naslov Humanizem in etika v socialnem delu, smo želeli klasičnim temam v socialnem delu in varstvu dodati še posebej aktualne teme, kot so globalne migracije (dr. Hubert Höllmüller, dr. Jelka Zorn), razprave o etičnih dilemah v socialnem delu (dr. Ana Marija Sobočan), odzivi socialnega dela na politične konflikte (prof. dr. Shulamit Ramon) in izkoriščevalski kapitalizem s kaznovalnimi socialnimi politikami (dr. Srečo Dragoš) in zeleno socialno delo (prof. dr. Darja Zaviršek in dr. Sonja Bezjak).

Tudi v Sloveniji se ukvarjamo z begunci, otroki brez spremstva in humanitarno pomočjo. Socialno delo je (skoraj) povsod po svetu udeleženo v procesih zagovorništva, krepitve moči uporabnikov, mobilizacije skupnosti; povečuje odpornost ljudi, samoodločbo, avtonomijo in spodbuja neodvisno življenje - vse to je del globalne etike socialnega dela. Hkrati se socialne delavke vse pogosteje srečujejo z omalovaževanjem svojega dela in kaznovalno državno administracijo, ki naj bi jo izvajali upravni delavci. Še več, strokovno razvrednotenje socialnih delavk in delavcev ter razvrednotenje področja socialnega varstva in zato nemoč, ki jo doživljajo strokovne delavke, uničujejo vitalno moč stroke in oddaljujejo disciplino socialnega dela od prakse. Zdi se, da se je v tridesetih letih samostojne države zgodila prava razgradnja socialnega dela, saj je njegov položaj danes slabši, kot je bil v desetletjih socialističnega socialnega dela (1955-1991).

Pričakujemo, da se bo moralo socialno delo v bližnji prihodnosti aktivno vključevati $v$ reševanje okoljevarstvenih problemov, tudi v boj proti nevarni industriji, za pitno vodo, proti škodljivi hrani, saj je vse to povezano z družbenimi neenakostmi, zdravjem, neprostovoljnimi migracijami in pomanjkanjem dobrin v prihodnosti, celo s preživetjem naše vrste in planeta, kakršnega poznamo.

Ko govorimo o etiki socialnega dela, si moramo vedno znova postavljati znani vprašanji: kakšne napetosti povzroča to, da je socialno delo podizvajalec državnih odločitev in hkrati avtonomna disciplina in stroka? Kaj so etične dileme, s katerimi se srečujejo socialne in druge strokovne delavke v centrih za socialno delo, v nevladnih organizacijah in povsod, kjer delujejo?

Eden od poglavitnih razlogov za nastanek socialnega dela konec 19. in na začetku 20. stoletja je bila revščina posameznikov, družin in skupnosti. V Sloveniji danes četrtina prebivalstva doživlja občasno, trajno in situacijsko revščino in socialne delavke so vsak dan priče revščini, ki jo ljudem povzročajo različne 
sistemske in osebne okoliščine. Za kakovostno delo v praksi potrebujemo na zelo natančnih podatkih utemeljeno raziskovanje obstoječih in ponavljajočih se socialnih problematik na eni strani ter socialne politike, varstva in prakse socialnega dela na drugi strani. $\mathrm{V}$ primerjavi z zahodnimi in nekaterimi postsocialističnimi državami imamo velik manko na področju aplikativnih raziskav, ki bi imele za cilj dograjevanje socialnodelovne prakse. Po objavi raziskovalnih ugotovitev se praksa ne spremeni, pa bi se morala.

Na sedmem kongresu socialnega dela smo ugotovili, da potrebujemo veliko več raziskav, ki bi nam pokazale, kako naprej, in manj deskriptivnih raziskovanj, ki v socialnem okolju ohranjajo status quo ali celo slabo prakso. Tematska številka Socialnega dela podaja nekaj takšnih znanstvenih odgovorov.

Darja Zaviršek, Sonja Bezjak

April 2021 